\title{
Sağlık Okuryazarlığı Araştırmalarının Bibliyometrik Analizi
}

\section{Bibliometric Analysis of Researches on Health Literacy}

iD

Selahattin Akyüz

${ }^{1}$ Dışkapı Yıldırım Beyazıt Eğitim ve Araştırma Hastanesi

\section{Öz}

Amaç: Son yıllarda tüm paydaşlar için önem kazanan sağlık okuryazarlığı, bireylerin alacakları sağlık hizmetlerine ulaşmada verecekleri kararlara etki edecek temel sağlık bilgileri ve bu hizmetleri anlama kapasiteleri olarak tanımlanabilir. Alan yazında sağlık okuryazarlığıyla ilgili yapıllan araştırmaların son zamanlarda artış gösterdiğı görülmektedir. Bu araştırmanın amacı, yapılan araştırmalar çerçevesinde, sağlık okuryazarlığı alanının bilimsel haritasının stratejik ve tematik olarak ortaya konulmasıdır

Gereç ve Yöntem: Bu çalışmada kullanılan veriler 1975-2019 yıllarını kapsayacak şekilde Web of Science (WoS) veri tabanından elde edilmiştir. Elde edilen veriler R tabanlı Bibliometrix analiz programında web arayüz sağlayıcısı olan Biblioshiny programı ile analiz edilmiş ve görselleştirilmiştir.

Bulgular: Araştırmada 401 kaynak içerisinde 808 belgeye ulaşılmıştır. Sağlık okuryazarlığı ile ilgili yapılan araştırmalarda 2004 yılından itibaren artış olmuştur. En fazla yayın ABD'de yapılmıştır. Kavramsal ağlarda "Health Literacy” teması öne çıkmıştır. Doküman ortak atıf ağında Berkman tarafından yayınlanan dokümanın öne çıktığı, yazar ortak atıf ağında merkezi kümede en önemli yazarın Baker, kaynaklara ilişkin ağda merkezi kümede en önemli kaynağın Journal of General Internal Medicine dergisi olduğu görülmüştür. Kripalani, en çok işbirlikçi ağa sahip yazar ve Northwestern Üniversitesi en işbirlikçi kurumdur.

Sonuç: Bu araştırma bulgularının ilgili tüm paydaşlara yol gösterici olacağı düşünülmüştür. Ayrıca sağlık okuryazarlığı ile ilgili farkındalığı artırıcı bilimsel faaliyetlerin düzenlenmesinin ve desteklenmesinin gerektiği değerlendirilmiştir.

Anahtar Kelimeler: Sağlık okuryazarlığı, Bilim haritalama, Bibliyometrik analiz, Bibliyometrix, Biblioshiny

Abstract

Objective: Health literacy, which has gained importance for all stakeholders in recent years, can be defined as basic health information that will affect the decisions of individuals in accessing health services and their capacity to understand these services. In the literature, it is seen that the studies on health literacy have increased recently. The aim of this research is to present the scientific map of the field of health literacy strategically and thematically within the framework of the researches.

Materials and Methods: The data used in this study were obtained from the Web of Science (WoS) database covering the years 1975-2019. The data obtained were analyzed and visualized in the $\mathrm{R}$ based Bibliometrix analysis program with the web interface provider Biblioshiny.

Results: In the research, 808 documents were reached among 401 sources. There has been an increase in research on health literacy since 2004 . The most publications have been made in the USA. The theme of "Health Literacy" has come to the fore in conceptual networks. It has been seen that the document published by Berkman stands out in the document co-citation network, the most important author in the central cluster in the author co-citation network is Baker, and the most important source in the central cluster in the reference network is the Journal of General Internal Medicine. Kripalani is the author with the most collaborative network and Northwestern University is the most collaborative institution.

Conclusion: It is thought that the findings of this research will guide all relevant stakeholders. In addition, it was evaluated that scientific activities that will raise awareness about health literacy should be organized and supported.

Keywords: Health literacy, Science mapping, Bibliometric analysis, Bibliyometrix, Biblioshiny

Yazışma Adresi: Selahattin Akyüz, Dışkapı Yıldırım Beyazıt Eğitim ve Araştırma Hastanesi, 06200, Altındağ / Ankara

E-Posta: selahattinakyuz@hotmail.com

Alınma tarihi: 27.07.2021 / Kabul tarihi: 02.08.2021 / Yayımlanma tarihi: 15.12.2021

Sağlık Okuryazarlığı Araştırmalarının Bibliyometrik Analizi - Akyüz.

Genel Tip Derg 2021;31(4)402-416 


\section{Giriş}

İçinde bulunduğumuz yüzyılda bilgi toplumları, sağlıkla ilgili karar verme paradoksu ile karşı karşıyadır. İnsanlar, sağlıklı yaşam tarzı seçimleri yapma ve sağlık hizmetleri sistemleri aracılığıyla kişisel ve ailevi sorunları yönetme konusunda giderek daha fazla zorlanmaktadır. Modern toplumlarda sağlıksız yaşam tarzları pazarlanmakta, iyi eğitimli insanlar için bile sağlık hizmeti sistemleri arasında tercihler yapmak giderek zorlaşmaktadır. Eğitim sistemleri, insanların bu kapsamda bilgilendirilmesi ve yeterli beceri sağlamalarında sıklıkla başarısız olmaktadır (1). Sağlık okuryazarlığı konusunda yapılan bir çalışmada, sekiz yıl ve daha az eğitim alan hastaların yetersiz işlevsel sağlık okuryazarlığına sahip olma olasılığının yüksek olduğu, buna karşın, lise sonrası öğretim almış hastaların yeterli işlevsel sağlık okuryazarlığına sahip olma olasılığının yüksek olduğu vurgulanmaktadır (2).

Tıbbi bakımın temel yönlerinden birisi hekim-hasta iletişimi olarak kabul edilir. Sağlık okuryazarlığı bağlamında değerlendirildiğinde, hastaların genellikle hekimlerin tıbbi talimatlarını anlamakta güçlük çektikleri görülmektedir. Hekimler genellikle tıbbi jargon kullanırlar, bir seferde çok fazla bilgi verirler ve hastaların tartışılanları anladıklarını doğrulamazlar. Hastalar, hekimin açıklamaya çalıştıklarının yarısından daha azını hatırlar ve bundan sonra hangi adımları atacakları konusunda kararsız olabilirler (3).

Sağlık okuryazarlığı son yıllarda tüm dünyada büyük ilgi görmektedir. Konuyla ilgili yapılan araştırmalar, sağlık literatürünün optimize edilmesinin, sağlığı ve refahı iyileştirmede, aynı zamanda sağlığa erişim eşitsizliklerini azaltmada büyük bir potansiyeli olduğunu göstermektedir (1). Sağlık okuryazarlığı, "bireylerin, uygun sağlık kararlarını almak için gereken temel sağlık bilgilerini ve hizmetlerini elde etme, işleme ve anlama kapasitesine sahip olmaları" şeklinde tanımlanmaktadır. Sağlık okuryazarlığı ile kişisel yaşam tarzlarını ve koşullarını değiştirerek, kişisel sağlığı ve toplum sağlığını iyileştirmek için harekete geçmek amacıyla belirli bir bilgi, beceri ve güven seviyesine ulaşılması amaçlanmaktadır. Sağlık okuryazarlığı düşük olan bireylerin sağlıklarının kötü olma olasılı̆̆ 1 daha yüksek, sağlık sorunlarını ve tedavi yönetimini anlama olasılıkları daha düşük ve hastaneye yatma sıklıkları ortalamanın üstündedir $(4,5)$. Yapılan çalışmalar, sağlık okuryazarlığ uygulamalarının hastaların sağlık çıktılarında iyileşmelere neden olduğunu göstermektedir (6-8).

Genel olarak yaşlı insanların daha düşük fonksiyonel sağlık okuryazarlığına sahip olduğu ifade edilmektedir. ABD Sağlık Bakım Stratejileri Merkezi tarafından yapılan incelemelere göre, düşük fonksiyonel sağlık okuryazarlığının 32 ila 58 milyar Dolar ek sağlık bakımı maliyetine neden olduğu tahmin edilmektedir. Söz konusu ek maliyetler arasında fazladan hastane yatışları ve ziyaretleri, hastanede kalış süresinde artış, ekstra tahlil, tetkik ve reçete edilen ilaçlar yer almaktadır (9).

Son zamanlarda, sağlık okuryazarlığı alanındaki araştırmaların arttığı görülmektedir. Avrupa'da sağlık okuryazarlığı araştırmalarının görselleştirildiği ve 1991-2005 dönemini kapsayan bir çalışmada, 25 Avrupa ülkesi ve ABD'den gelen veriler incelenmiş; çalışma bulguları, Avrupa ülkelerinin ABD'ye kıyasla sağlık okuryazarlığı alanında üçte birden daha az araştırma ürettiğini göstermiştir. Çalışmada, Hollanda, İsveç, Almanya, İtalya ve Fransa, sağlık okuryazarlığı alanında en çok yayımlanmış araştırmaya sahip Avrupa ülkeleri olarak öne çıkmıştır.
Yapılan ikinci çalışmayla Avrupa halkının sağlık okuryazarlığı incelenmiştir. Çalışma bulguları, ankete katılan toplam nüfusun \%10'dan fazlasının yetersiz düzeyde sağlık okuryazarlığına sahip olduğunu göstermiştir. Bu oranın bazı ülkelerde \%30 seviyesine kadar ç1ktığı görülmüştür (10-12).

Sağlık okuryazarlığı konusunda Türkiye'de yapılan bir araştırmaya göre, yaşlı nüfusun \%85,1'inde sağlık okuryazarlığının yetersiz olduğu, yetersizliğin sağl1k hizmetlerinden yararlanmada $\% 63,5$, hastalıklardan korunmada $\% 86,9$ ve sağ 1 ğın iyileştirilmesinde $\% 87,6$ oranında olduğu ifade edilmiştir. Konu bağlamında yapılan diğer bir araştırmada, sağlık okuryazarlığı seviyesini ölçen iki farklı testle okuryazarlık seviyeleri analiz edilmiş ve çalışma grubunun sırasıyla $\% 58,7$ 'sinin ve $\% 28,1$ 'inin yeterli sağlık okuryazarlığına sahip olduğu, çalışma grubunun tıbbi kelime tanıma ve telaffuz kapasitesinin sayısal ve muhakeme yeteneklerine göre daha iyi olduğu belirlenmiştir (13, $14)$.

Dünyada bilimsel yayınların sayısı hızlı bir şekilde artmakta, bu artışla beraber bilimsel gelişmelerin takibi de zorlaşmaktadır. Farklı bilim alanlarında veya bunlara ait alt alanlardaki değişimin bilim insanlarınca izlenmesi hayati önem taşımakta olup akademisyenlerin güncel kalmaları ve gereksinim duydukları verilere her an ulaşmaları gerekmektedir. Bu talep ve gereksinimler bibliyometrik yöntemlerin kullanımını da bu ölçüde artırmıştır. Bibliyometri, "belirlenen alanda ve zamanda, belirlenen kişiler ya da kurumlar tarafindan kaleme alınmış eserlerin ve bunlar arasındaki ilişkilerin analizi" şeklinde tanımlanabilir. Bu araştırmada sağlık okuryazarlığı konusu, bibliyometrik analiz teknikleri ile ele alınmış ve konu literatür kapsamında değerlendirilmiştir $(15,16)$.

Bibliyometri, veri tabanlarından sağlanan verilerde analizlerin yapılması temeline dayanmaktadır. Bu analizlerle, üzerinde çalışılan konunun disiplinin panoramik görüntüsü elde edilebilir. Böylelikle üzerinde çalışılan konu veya disiplinle ilgili araştırmacı ve eserler bağlamında bilgi edinilebilir, yayın performansları hakkındaki verilere erişilebilir. Bibliyometrik analiz, mevcut literatürü tarayıp konuyu bir bütüncül olarak görmeyi sağlamakta, eserlerin atıf performansları ile ilgili bilgi vermektedir. Bu bilgiler eserlerin bilimsel seviyesinin saptanmasında önemlidir. Bibliyometrik yöntemlerle yapılan atıf analizleriyle literatürün yaşlanma hızı belirlenebilmekte ve kütüphanelerin ilgili literatüre yönelik çalışmalarında verecekleri kararlara destek olunabilmektedir (17-19).

Bibliometrix; R dilinde geliştirilmiş, mantıksal bir iş akışına göre istatistiksel hesaplama yapan ve aynı zamanda grafik oluşturabilen benzersiz bibliyometrik bir araçtır. R, nesne yönelimli ve işlevsel bir programlama dilidir, bu özelliğinden dolayı genişletilebilmektedir. Bu dille, analizleri otomatikleştirmek ve yeni işlevler oluşturmak oldukça kolaylaşmaktadır. Açık yazılım niteliğine sahip olan Bibliometrix, esnektir, hızla yükseltilebilir ve diğer istatistiksel $\mathrm{R}$ paketleri ile entegre edilebilir. $\mathrm{Bu}$ nedenle, bibliyometri gibi sürekli değişen bir bilim disiplininde oldukça kullanışlıdır. Bibliometrix tüm temel bibliyometrik analiz yöntemlerini içermektedir ancak özellikle bilim haritalama için kullanılmaktadır (20). Literatürde sağlık okuryazarlığı konusunda yapılmış olan bibliyometrik analizleri içeren çalışmalar bulunmakla birlikte R tabanlı bibliyometrix programı ile yapılan herhangi bir çalışmaya rastlanamamıştır $(10,21,22)$.

Bu bağlamda bu çalışmanın amacı, sağlik okuryazarlığı konusunda 
yayımlanan akademik makalelerin $\mathrm{R}$ tabanlı bibliometrix programı kullanılarak bibliyometrik analizinin yapılmasıdır.

\section{Yöntem}

Amacı sağlı okuryazarlığı konusunda yayımlanan akademik makalelerin bibliyometrik analizini yapmak olan çalıșmada "Health Literacy" konusunun araştırılması yapılırken izlenen aşamalar Şekil 1 'de akış şeması olarak gösterilmiştir.

Birinci adım, araştırma konusu hakkında en kaliteli verilere ulaşılabilecek veri tabanı seçmektir. Dünya üzerinde genel kabul görmesi ve yüksek kaliteli akademik makaleleri bulundurması nedeniyle bu çalışmanın verileri Web of Science (WoS) Core Collection tabanından alınmıştır.

İkinci adım, veri tabanında bulunan etkili makaleleri ayıklamak ve filtrelemektir. Doğru ve gerçekçi bir veri analizi yapabilmek için WoS veri tabanında [TITLE: ("healthcare management") OR TITLE: ("health care management") OR TITLE: ("healthcare") OR TITLE: ("Health Care") OR TITLE: ("Health Services") OR TITLE: ("Healthcare Services") OR TITLE: (Hospital) OR TITLE: (Clinics) OR TITLE:(Pharmacy) OR TITLE: ("Primary Care") Refined by: TOPIC: ("health literacy") Timespan: 1975-2019 Indexes: SCIEXPANDED, SSCI] parametreleri kullanılarak arama yapılmıştır. Böylece makale konusu "Health Literacy" olan etkili makalelere ulaşılmıştır. Veri tabanına erişim tarihi 23.10.2020 olup, veri tabanından veriler toplanırken 2020 yılı henüz sonlanmadığından 2020 tarihli makaleler kapsam dışı bırakılmıştır. Çalışma, yapılan filtreleme sonucu 1995-2019 yılları arasında yayımlanan 808 makale kullanılarak gerçekleştirilmiştir.

Üçüncü adım, filtreleme sonucu ulaşılan makalelerin bibliyometrik analizini yapmaktır. $\mathrm{Bu}$ aşamada içerik analizini $\mathrm{R}$ ortamında geliştirilen "bibliometrix 3.0" programı ve bu programın kullanımı ve görselleştirilmesi için geliştirilen bir web arayüzü sağlayıcısı olan "biblioshiny" kullanılmıştır (23).

Sağlık okuryazarlığı ("Health Literacy”) konusunun içerik analizi Şekil 1'de gösterilen şemaya uygun olarak çalışma hakkında istatistikleri içeren genel yapı analizi ve mantıksal ağ grafikleri içeren entelektüel yapı analizi olmak üzere iki ana başlık altında yapılmıştır.

\section{Bulgular}

\section{Genel Yapı Analizi}

Çalışmanın bu bölümünde Veri Seti, Kaynak Analizi, Yazar Analizi ve Belgelerin Analizi başlıkları altında konuya ilişkin genel istatistikler incelenmiştir.

\section{Veri Seti}

"Health Literacy" teriminin bibliometrix programı kullanılarak yapılan analizi sonucunda, toplam 401 kaynak içerisinde 808 belgede bu konuya rastlanıldığ 1 görülmektedir. Makaleler 648 adet ile yayın türleri arasında terimin en çok kullanıldığ olmuştur. Çalışma konusu hakkında 3522 yazarın yayın yapmış olmasına rağmen, tek yazarlı yayın sayısının 47 adetle sınırlı kaldığı ve bu konuda çalışma yapan yazarların çok yazarlı yayın eğiliminde oldukları görülmektedir.
Bibliometrix kullanılarak alınan sonuçların birleştirilmesi ile elde edilen Yıllık Bilimsel Üretim ve Ortalama Alıntılar grafiği Şekil 2 'de gösterilmiştir. Her yıl health literacy konusuyla ilgili olarak 1995 yılından itibaren kaç yayın yapıldığı ve yayın yıllarına göre çalışmaların aldığı atıf sayısının yayın sayısına bölünmesi ile elde edilen atıf ortalamaları Excel ortamında grafiğe dökülmüştür.

Konuyla ilgili olarak 1995-2019 yılları arasında yapılan yayın sayısında önemli bir artış gözlendiği; 2001 yılına kadar yapılan yayın sayısının 9 olduğu ve sadece 2018 yılında yayın sayısının 110'a ulaştığı görülmektedir. Bu kapsamda health literacy alanının geçmişe göre popülerliğinin giderek arttığı gözlenmektedir.

Y1llık ortalama alıntılanma grafiği değerlendirildiğinde, 1995 y1lında yayımlanan bir yayın olmasına rağmen, alanında ilk olması ve atıf alabileceği yıl sayısının 20 yıldan fazla olması sebebiyle \%25,3 oranla en yüksek yıllık atıf oranına sahip olduğu; 2010 yılından sonra ise daha yüksek sayılarda yayın yapılmış olmasına rağmen atıf yüzdelerinin düşük kaldığı belirlenmiştir.

Grafik üzerinde $\mathrm{R}^{2}$ olarak belirtilen değer, regresyon katsayısı olarak ifade edilen ve belirlenen grafiğin üzerine eğilim eğrisi eklendiğinde eğri denkleminin grafik değerlerini ne kadar doğru yansıttığını anlamamızı sağlayan katsayıdır ve 1'den büyük olamaz. Bu değer 1'e ne kadar yakınsa eğilim eğrisinin grafikteki değerleri temsili o kadar yüksek demektir. Yıllık Bilimsel Üretim grafiğine eklenen eğilim eğrisinin $\mathrm{R}^{2}$ değerinin 0.9748 olduğu ve bu sayının 1'e çok yakın olduğu göz önüne alındığında, grafik üzerinde gösterilen eğilim eğrisi denkleminin grafikteki değerleri çok doğru temsil ettiği anlaşılmaktadır.

Analiz bulgularına göre sağlık okuryazarlığı alanında en fazla yayın yapan ülkelerin Amerika, Avusturalya, Kanada, İngiltere ve Almanya olduğu belirlenmiştir. Veri setinde en sık kullanılan anahtar kelimelerin ülkeler ve dergiler arasındaki ilişkilerini gösteren üç alan grafiği bulgularına göre sağlık okuryazarlığ 1 konusunda en sik kullanılan anahtar kelimenin health literacy olduğu ve bunun da ülke bazında en yoğun ilişkisinin Amerika ile olduğu görülmektedir. Yani sağllk okuryazarlığı alanında ilk sırada yer alan ve oldukça fazla yayına sahip olan Amerika'nın en sık kullandığı anahtar kelime yine anahtar kelimeler içerisinde ilk sırada yer alan health literacy olmuştur. Health literacy anahtar kelimesinin ilişkili olduğu kaynaklara bakıldığında Patient Education and Counseling ve BMC Health Services Research dergilerinin ön plana çıktığı görülmektedir.

\section{Kaynak Analizi}

Health literacy konusu özellikle Amerika başta olmak üzere birçok ülkede üzerinde çalışılan bir konu olması nedeniyle çok çeşitli dergilerde çalışmalar yayımlanmıştır. Sağlık okuryazarlığı konusunda yayın yapan dergilerin makale yayın sayıları, h-indeksleri, atıf sayıları ve atıf sayısının yayın sayısına oranları (Total Citation/Number of Publication; TC/NP) değerlendirildiğinde Patient Education and Counseling dergisi 28 makaleyle ilk sirada yer alarak bu alanda en fazla yayın yapan kaynak olmuştur. Bu kaynağ sırasıyla BMC Health Services Research $(\mathrm{n}=25)$ ve Journal of General Internal Medicine $(\mathrm{n}=25)$ takip etmektedir. H-indeksi bir derginin ya da yazarın yayımlanan makalelerinin etkinlik derecesini anlayabilmek için oluşturulmuş bir değerlendirme ölçütüdür. Kısaca h sayıda makalenin en az h sayıda atıf almış olması olarak açıklanmaktadır. Makale sayısında ilk sırada bulunan Patient Education and Counseling dergisi 
h-indeks siralamasında da ilk sırada bulunmaktadır ve bu alanda en etkili kaynaktır (h-indeks=14). Makale sayısı olarak ilk üç sırada olmamasına rağmen $12 \mathrm{~h}$-indeksine sahip olan Journal of Health Communication dergisi de health literacy alanında etkili dergiler arasında yer almaktadır.

En çok atıf toplayan dergi 1075 atıf sayısı ile Journal of General Internal Medicine dergisidir. Atıf sayısının yayın sayısına oranı (TC/ $\mathrm{NP}=43$ ) en yüksek kaynak olan Journal of General Internal Medicine dergisi yayına başlama tarihi olarak (1998) en eski tarihe sahip dergi olduğu için çalışma alanındaki en etkili dergi olarak nitelendirilebilir. Makale sayısı olarak daha fazla makaleleri bulunan ilk iki sıradaki Patient Education And Counseling ve BMC Health Services Research dergileri ise sırasıyla 2007 ve 2012 yıllarında yayın hayatına başlaması nedeniyle yeterli atıf alabilecek süreye sahip olmadığından TC/NP oranları daha düşüktür.

Akademik kaynakların analizi sırasında kullanılan bir yöntem de Bradford Yasası'dır. İlk olarak 1934 yılında ortaya çıkan bu yasaya göre belirli bir konu hakkında yayımlanan bütün makalelerin üçte biri yalnızca küçük bir çekirdek dergi grubu tarafindan yayımlanmıştır. $\mathrm{Bu}$ çekirdek grup belirlenen disiplindeki en etkili dergi grubu olarak nitelendirilebilir. İkinci üçte birlik dilim çekirdek grubun yaklaşık "n" katı sayıda, son dilim ise çekirdek grubun yaklaşık " $\mathrm{n}$ "” katı sayıda dergi içermektedir. İkinci gruptaki dergiler daha az etkili dergiler olarak, üçüncü gruptaki dergiler ise etkisiz dergiler olarak değerlendirilebilir (24). Bradford Yasasına göre yapılan analizde çalışma alanının çekirdek grubunda 24 dergi bulunmaktadır. Bu dergiler 269 yayınla toplam yayın sayısının \%33,29'una sahiptir. Çekirdek gruptaki kaynak sayısı toplam kaynak sayısına oranlandığında \%6'ya yakın bir orana sahip olduğu görülmektedir. Bu oran Bradford Yasası'nda belirtilen orana göre daha yüksek olup çalışma alanındaki çekirdek grubun fazlasıyla büyük olduğu söylenebilir.

\section{Yazar Analizi}

Yazar analizinde yazarların yayın sayıları, h indeksi, $\mathrm{m}$ indeksi, toplam atıfları (TC) ve health literacy alanındaki ilk yayın yılları dikkate alınmıştır. Sağlık okuryazarlı̆g 1 konusunda en fazla yayın yapan yazarların Kripalani S ( $\mathrm{n}=17)$, Wolf MS ( $\mathrm{n}=16)$ ve Davis TC $(n=14)$ olduğu belirlenmiştir.

H-indeksi bir yazarın "h" adet yayının en az "h" kadar atıf almış olduğunu belirten ve yazarın sadece atıf sayısını değil bu atıfların ne kadar istikrarlı olduğunu da belirten indekstir (25). Health literacy alanında yayın yapan yazarlar arasında h-indeksi en yüksek yazar Kripalani S'dir (h-indeks=13). Bu yazardan sonra en yüksek değere sahip yazar Paasche-Orlow MK (h-indeks=9) olup bu yazardan sonra h-indeksi 8 olan Wolf MS, Davis TC ve Parker RM gelmektedir.

M-indeksi genç bilim adamlarının yeterli atıf alabilecek zamanlarının olmaması dezavantajını ortadan kaldırmak üzere üretilmiş bir indekstir (26). Yazarın h-indeksinin, çalışma alanında yayımlanan ilk makalesinin yayında kaldığı süreye bölünmesiyle bulunmaktadır. M-indeksine göre 2003 yılında ilk yayınını yapan Kripalani S (m-indeks $=0,722)$ ilk sirada bulunmaktadır. İkinci sırada yayın hayatına 2013 yılında başlayan Osborne RH (m-indeks $=0,625)$ yer almaktadır. Osborne RH henüz 6 yayın yapmış olmakla birlikte gelecekte alanın etkili yazarlarından biri olacağı değerlendirilmektedir.

Yazarların aktif oldukları dönemlerin incelenmesi de etkili yazar olup olmadıklarını anlama konusunda önemli bir göstergedir. Şekil 3a'da yazarların zaman içerisindeki üretkenliği gösterilmiştir. Şekil üzerindeki dairelerin büyüklüğü makale sayısının artışını ifade ederken, renk tonunun koyulaşması yıllık atıf oranının artışını göstermektedir. Bir y1l içerisinde en fazla makale üreten yazar 2015 yılında yayınladığı dört makale ile Wolf MS olmuştur. En yüksek yıllık atıf oranı ise 77.67 ile 2009 yılında Paasche-Orlow MK ve Jack BW tarafindan paylaşılmaktadır. Davis TC, 1998 yılından itibaren üretkenliğine devam etmiş ve 2019 yılına kadar hem makale üretmiş hem de atıf almaya devam etmiş olup etkili yazarlar arasında en uzun süre üretken olan yazar olmuştur. Health literacy alanında yayın yapmış yazarların Lotka Yasasına göre dağılımları Şekil 3b'de sunulmuştur. Lotka Yasası'na göre bir çalışma alanında yazarların \%60'ının sadece bir makale, \%15'inin iki makale, \%7'sinin üç makale yayınladığı ve alandaki spesifik makale sayısı arttıkça bu oranın katlanarak düşeceği öngörülmektedir (27). Grafikte health literacy konusuna bir makale ile katk1 sağlayan yazar oranı \%90,5 olarak görülmektedir. Lotka Yasası'na göre çok daha yüksek olan bu oran veri setindeki yazarların çok büyük çoğunluğunun sadece bir makale ile alana katkı sağladığını göstermektedir. İki yayınla katkı sağlayan yazarlar \%6,5'ini, üç yayınla katkı sağlayan yazarlar \%2'sini, dört yayınla katk1 sağlayanlar \%0,5'ini oluşturmaktadır. Bu bulgulara göre health literacy alanında 5 ve daha fazla yayın yapan yazarların alanının çekirdek ve etkili yazarları olduğu değerlendirilmektedir.

\section{Belgelerin Analizi}

Bibliyometrik analizlerde yayınlar özelinde incelemeler yapılırken yazarlar tarafindan seçilen anahtar kelimeler büyük önem taşımaktadır. Anahtar kelimelerin makalenin içeriğini temsil ettiği değerlendirildiğinde, kelime analizi araştırma konusunun günümüzdeki ana temalarını ve gelecekte evrimleşeceği temaları görebilmek adına büyük önem taşımaktadır. Health literacy alanındaki kelime bulutları Şekil 4a'da yer almaktadır. Keyword Plus, Author's Keywords (Yazar Anahtar Kelimeleri), Titles (Başlıklar) ve Abstract (Özet) seçeneklerinde en s1k karşılaşılan 50 kelime görselleştirilmiştir. Anahtar kelimelerin sıklığı çubuk grafiği olarak sunulmuştur. Kelime bulutlarında kelimelerin büyüklükleri görülme sıklığıyla doğru orantılı olarak artmaktadır.

"Titles" seçeneğine göre veri setindeki yayınların başlıklarında en çok kullanılan ilk üç anahtar kelimenin "health", "care" ve "literacy" olduğu, "abstract" seçeneğinde özetler içinde en çok kullanılan ilk üç anahtar kelimenin "health", "literacy" ve "patients" olduğu görülmektedir. "Author's Keywords" seçeneğinde yazarlar tarafından belirtilen anahtar kelimeler arasında en çok kullanılan ilk üç anahtar kelime "health literacy", "primary care" ve "health" olmuştur. "Keywords Plus" seçeneği ise WoS Core Collection tarafindan geliştirilen bir algoritmaya sahip olup, veri setindeki yayınların referans listelerinde olup atıf yapılan makalelerin başlıklarının analiz edilmesiyle ortaya çıkarılan bir kelime sıklığı analizi seçeneği olup, en çok kullanılan ilk üç anahtar kelime "care", "literacy" ve "outcomes" olarak belirlenmiştir.

Anahtar kelimelerin zaman içerisindeki dinamik analizi dört zaman diliminde grafik olarak Şekil 4b'de sunulmuştur. Zaman dilimleri belirlenirken ilk dilim akademik makale sayısının düşük olması nedeniyle 7 sene (1998-2004) geri kalan seneler ise beşer senelik dilimlere bölünmüştür. Bütün yazar anahtar kelimeleri yıllara göre sürekli artış eğiliminde olmasına rağmen en anlamlı yükselişi health 
literacy anahtar kelimesi yaparak kullanım sıklığı en çok artan anahtar kelime olmuştur. Health literacy anahtar kelimesini, kelime bulutlarındaki bulgulara paralel olarak, primary care ve health anahtar kelimeleri takip etmektedir.

Yayınların yıllar içerisindeki gelişim dinamiklerini incelemek adına Atıf Analizi de yaygın olarak kullanılmaktadır. Health literacy konusunda en çok atıf toplayan ilk 20 makale Global Atıf (Global Citation; GC) sayısına göre Tablo 1'de listelenmiştir.

Tablo 1. En Çok Atıf Alan İlk 20 Makale

\begin{tabular}{|l|c|c|c|c|c|c|c|}
\hline Doküman & YP & YYP & LC & $\begin{array}{c}\text { LC/ } \\
\text { YYP }\end{array}$ & GC & $\begin{array}{c}\text { GC/ } \\
\text { YYP }\end{array}$ & LC \\
\hline WEISS BD, 2005 & 2005 & 15 & 55 & 3.667 & 1041 & 69.400 & 5.28 \\
\hline JACK BW, 2009 & 2009 & 11 & 17 & 1.545 & 932 & 84.727 & 1.82 \\
\hline WILLIAMS MV, 1995 & 1995 & 25 & 33 & 1.320 & 632 & 25.280 & 5.22 \\
\hline BAKER DW, 2002 & 2002 & 18 & 52 & 2.889 & 553 & 30.722 & 9.40 \\
\hline BAKER DW, 1998 & 1998 & 22 & 46 & 2.091 & 481 & 21.864 & 9.56 \\
\hline KRIPALANI S, 2007 & 2007 & 13 & 6 & 0.462 & 447 & 34.385 & 1.34 \\
\hline BAKER DW, 1997 & 1997 & 23 & 33 & 1.435 & 418 & 18.174 & 7.89 \\
\hline SCOTT TL, 2002 & 2002 & 18 & 30 & 1.667 & 416 & 23.111 & 7.21 \\
\hline CORRIGAN PW, 2014 & 2014 & 6 & 2 & 0.333 & 357 & 59.500 & 0.56 \\
\hline ROTHMAN RL, 2004 & 2004 & 16 & 11 & 0.688 & 238 & 14.875 & 4.62 \\
\hline SUDORE RL, 2006 & 2006 & 14 & 12 & 0.857 & 210 & 15.000 & 5.71 \\
\hline PARKER RM, 2003 & 2003 & 17 & 10 & 0.588 & 199 & 11.706 & 5.03 \\
\hline THORNICROFT G, 2007 & 2007 & 13 & 2 & 0.154 & 179 & 13.769 & 1.12 \\
\hline SMITH SK, 2009 & 2009 & 11 & 7 & 0.636 & 171 & 15.545 & 4.09 \\
\hline KRIPALANI S, 2012 & 2012 & 8 & 6 & 0.750 & 158 & 19.750 & 3.80 \\
\hline DAVIS TC, 1998 & 1998 & 22 & 10 & 0.455 & 152 & 6.909 & 6.58 \\
\hline BATTERHAM RW, 2016 & 2016 & 4 & 4 & 1.000 & 140 & 35.000 & 2.86 \\
\hline ZIEMER DC, 2005 & 2005 & 15 & 0 & 0.000 & 139 & 9.267 & 0.00 \\
\hline PAASCHE-ORLOW MK, & 2006 & 14 & 11 & 0.786 & 137 & 9.786 & 8.03 \\
\hline 2006 & 2009 & 11 & 0 & 0.000 & 134 & 12.182 & 0.00 \\
\hline GIACAMAN R, 2009 & & & & & & & \\
\hline
\end{tabular}

Year of Publication-YP:Yayın Y111; Year 2020-Year of PublicationYYP:Yayın Süresi; Local Citation-LC:Yerel Atıflar; Global CitationGC:Global Atıflar; LC(\%):LC/GC

Global atıf (GC) belirtilen makalenin WoS Core Collection veri tabanında toplamda kaç adet atıf aldığını belirtirken, Yerel Atıf (Local Citation; LC) bu çalışmada analiz edilen 808 makalenin içerisinde kaç adet atıf aldığını belirtmektedir (20). En fazla atıf alan makale Weiss BD (2005) olarak görülmektedir (LC:55; GC:1041). Corrigan PW tarafindan 2014 y1linda yayınlanan makale (GC:357) health literacy alanında etkili bir makale olarak değerlendirilebilecektir.

Atıf sayısı analizinde, son yıllarda yayınlanan yeni makalelerin atıf alabilmesi için yeterli süreye sahip olmaması sebebiyle, atıf sayılarının yayında kalınan süreye (Year 2020-Year of Publication; YYP) bölünmesi ile elde edilen Yıllık Yerel Atıf (LC/YYP) ve Yıllık Global Atıf (GC/YYP) değerleri de kullanılmaktadır. LC/YYP değeri en yüksek makale 3.667 ile yine Weiss BD (2005) olurken, GC/ YYP değeri en yüksek makale 84.727 ile Jack BW (2009) olarak belirlenmiştir.

Atıf analizi için geliştirilen bir diğer kavram ise Yerel Atıf Yüzdesidir. Yerel Atıf sayısının Global Atıf sayısına bölünmesi ile elde edilen bu değere göre veri seti içerisindeki en etkin makale $(\% 9,56)$ Baker DW (1998) tarafından yayınlanmıştır.

\section{Entelektüel Yapı Analizi}

Çalışmanın bu bölümünde analiz edilen yayınların Kavramsal, Entelektüel ve Sosyal olarak iletişimi ve bağlantıları incelenmiştir.

\section{Kavramsal Ağlar}

En sık kullanılan 50 anahtar kelimenin birbirleriyle olan ilişkilerini ve oluşum ağını gösteren görsel Şekil 5a'da sunulmuştur. Louvain Kümeleme Algoritması kullanılarak oluşturulan görselde her bir elips bir anahtar kelimeyi temsil ederken elipsler arasındaki çizgilerin kalınlığ kelimeler arasındaki ilişkinin yoğunluğu ile doğru orantılı olarak değişmektedir. Görselde anahtar kelimelerin beş farklı kümeye bölünmüş olduğu ve kümeler arasında merkeziliği en yüksek kümenin turuncu küme olduğu belirlenmiştir. Merkeze en yakın ve en yoğun bağlantıya sahip olan yeşil küme ve daha kalabalık bir küme olmasına rağmen iletişim ağının merkezine uzak olan mavi küme birbirleriyle ve merkezdeki turuncu kümeyle tematik olarak bağlidır. Dördüncü küme olarak görünen kırmızı küme ise merkezdeki turuncu küme dışında hiçbir kümeyle iletişim kurmamıştır. Mor küme ise hiçbir küme ile bağ kurmamaktadır. Turuncu kümenin merkezindeki health literacy anahtar kelimesi dışında küme merkezinde bulunabilecek bir anahtar kelime gözlenmemektedir. Health literacy kelimenin primary care ve communication kelimeleri ile kurduğu güçlü bağ aralarındaki çizginin kalınlığından anlaşılmaktadır.

Çalışma alanındaki araştırmaların 1998 yılından itibaren tematik gelişimini inceleyebilmek için 1998-2019 yılları dört zaman dilimine bölünerek incelenmiştir. Birinci dilim literatürün erken yılları olması sebebiyle yeterli sayıda makale bulunmaması nedeniyle yedi yıl olarak seçilip kalan dilimler beşer y1l olarak seçilmiştir (1998-2004, 2005-2009, 2010-2014, 2015-2019). Dönemlere ilişkin stratejik diyagramlar Şekil 5b'de verilmiştir.

Stratejik Diyagramlar, yatay ve dikey iki eksenle dört çeyreğe bölünmüş bir analiz grafiğidir. Yatay eksen merkeziliği belirtirken, dikey eksen ise yoğunluğu belirtmektedir. Grafikte eksenler tarafından oluşturulan dört bölgenin tanımlanması analiz açısından büyük önem taşımaktadır.

1'inci çeyrek: Sağ üst çeyrektir, yüksek yoğunluk ve yüksek merkeziliği ifade etmektedir. Bu çeyrekteki temalar "Motor Temalar" olarak isimlendirilmektedir. Bu çeyrekteki anahtar kelimelerle temsil edilen temalar birbirleriyle güçlü iç bağlara sahiptir ve çalışma alanını şekillendirmek için önemli temalardır.

2'inci çeyrek: Sol üst çeyrektir, yüksek yoğunluk fakat düşük merkeziliği ifade etmektedir. Bu çeyrekteki temalar "Gelişmiş ve İzole Temalar" olarak isimlendirilmektedir. Bu çeyrekteki temalar nispeten güçlü iç bağlara sahip olmasına rağmen, çalışma alanını şekillendirebilecek kadar önemli hale gelememiştir.

3'üncü çeyrek: Sol alt çeyrektir, düşük yoğunluk ve düşük merkeziliği ifade etmektedir. Bu çeyrekteki temalar "Yeni Ortaya Çıkan veya Kaybolan Temalar" olarak isimlendirilmektedir. Bu çeyrekteki temalar önemini kaybeden veya yeni çıkıp önemli bir rol oynayabilecek temaları temsil etmektedir. Çalışma alanı için düşük öneme sahip ancak yeni trendleri ve eski trendleri anlayabilmek adına takip edilebilecek çeyrektir.

4'üncü çeyrek: Sağ alt çeyrektir, düşük yoğunluk fakat yüksek 
merkeziliği ifade etmektedir. Bu çeyrekteki temalar "Temel ve Gelişimsel Temalar" olarak isimlendirilmektedir. Bu çeyrekteki temalar üzerinde çok fazla araştırma yapılmış olup merkeziliği çok yüksek olduğundan çalışma alanı için yüksek öneme sahiptirler (28).

Stratejik diyagram grafiklerinde en az beş kez tekrarlanan anahtar kelimeler incelenmiş olup, en çok tekrarlanan kelimeler kelime kümeleri halinde gruplanmıştır. Her kümenin en sık kullanılan kelimesi küme başlı̆ğ olmuştur.

Motor temalar incelendiğinde çalışma alanın ilk yıllarında bir küme oluşmuş olup bu kümeyi health education anahtar kelimesi temsil etmektedir. İkinci zaman dilimi olan 2005-2009 y1lları arasında küme sayısında artış görülmüş ve küme başlıkları olarak "mental health literacy", "access", "health" anahtar kelimeleri ön plana çıkmıştır. 2010-2014 yıllarında ise motor temalar çeyreğinde "education" ve "health information" kümesinin oluştuğu görülmektedir. "Health communication" kümesi de 1'inci çeyrekte olmasına rağmen düşük merkeziliğe sahip olduğundan orijine yakın yerleşmiştir. Çalışma alanın son döneminde ise "education" kümesi motor tema olarak kalmaya devam ederken yeni bir kavram olarak "depression" kelimesi de motor tema çeyreğinde yer almıştır.

Gelişmiş ve izole temalar incelendiğinde 2005-2009 döneminde "health disparity", 2010-2014 döneminde ise "instructions" anahtar kelimeleri yüksek merkeziliğiyle dikkat çekmektedir.

Yeni çıkan veya kaybolan temalar incelendiğinde, çalışma alanının ilk yıllarında motor tema olarak belirtilen "health education" anahtar kelimesi 2010-2014 yılları arasında bu çeyreğe kaydığı görülmüştür.

Temel ve gelişimsel temalar incelendiğinde ise çalışma alanın ilk zamanlarından itibaren en yüksek öneme sahip kelimenin "health literacy" olduğu görülmektedir. 2010-2014 döneminden "internet" ve 2015-2019 döneminden "mental health" kelimeleri de dikkat çekmektedir.

Temaların gelişimleri incelenmesinde önemli bir rol oynayan Tematik Evrim Haritası Şekil 5c'de yer almaktadır. Görselde akışları gösteren bağlantıların kalınlığı ilişkinin yoğunluğunu gösterirken, kümelerin boyutları anahtar kelime kullanım sıklığını ifade etmektedir. Çalışmanın ana konusu olan "health literacy" kelimesinin ilk dönemden son döneme kadar artarak devam ettiği ve son dönemde çok yüksek tekrar sayısına sahip olduğu görülmektedir. Ayrıca son dönemde "qualitative research" ve "health disparities" anahtar kelimelerinin bir önceki zaman dilimindeki "health literacy" temasından beslenen yeni ve önemli tematik alanlar olduğu görülmektedir.

\section{Entelektüel Ağlar}

Health literacy alanında yayımlanan literatürün entelektüel analizleri doküman, yazar ve kaynaklar için ortak atıf ağları ile değerlendirilmiştir. $\mathrm{Bu}$ ağlarda Louvain kümeleme algoritması kullanılarak en fazla atıf alan 50 doküman, yazar ve kaynak incelenmiştir. Görsellerdeki her bir elips bir dokümanı, yazarı veya kaynağı ifade etmekte olup aralarındaki çizgilerin kalınlığı iki doküman, yazar veya kaynak arasındaki ilişkinin yoğunluğuna göre değişmektedir.

Doküman ortak atıf ağı Şekil 6a'da sunulmuştur. Doküman atıf ağında dört farklı küme oluşmuş ve merkezi küme kırmızı küme olmuştur. $\mathrm{Bu}$ kümenin merkezinde ise en fazla ortak atıfa sahip doküman olan
Berkman (2011-1) yer almıştır. Mavi kümenin merkezinde NielsenBohlman (2004-1) yer alırken yeşil küme Parker (1995) etrafında şekillenmiştir. Dördüncü küme olan mor kümede ise sadece Jorm adlı yazarın makaleleri yer almaktadır ve diğer kümelerle atıf ilişkisi kurmamıştır. Kümeler içerisinde en güçlü atıf bağına sahip küme çizgi kalınlıklarından anlaşılacağı üzere kırmızı kümedir. En güçlü atıf bağı Chew (2004-1) ile Chew (2008) arasında kurulmuştur.

Yazar ortak atıf ağı Şekil 6b'de yer almaktadır. Yazarlar üç farklı kümeye ayrılmış olup en yüksek ortak atıf alan yazar en merkezi küme olan kırmızı kümenin merkezinde yer alan Baker olmuştur. Baker kendi kümesi içerisinde Parker, Gazmararian, Williams ve Weiss ile güçlü atıf bağlarına sahipken diğer kümelerle de atıf bağlarına sahiptir. Mavi kümenin merkezinde anonim yayınlar bulunmakta olup Berkman'ın küme içerisinde ortak ağı da yüksektir. Yeşil küme ise Nielsen-Bohlman merkezliğinde ve diğer iki kümeye göre ortak atıf sayısı daha düşük yazarlardan oluşmaktadır.

Kaynaklar arası iş birliğini gösteren ağ Şekil 6c'de sunulmuştur. Ağda en fazla ortak atıf alan küme kırmızı küme olarak görülmektedir. Kırmızı kümenin merkezinde ise Journal of General Internal Medicine dergisi bulunmaktadır. En güçlü atıf bağ kurduğu dergiler ise Patient Education and Counseling ve Journal of American Medical Association dergileri olmuştur. Mavi kümenin merkezinde Social Science \& Medicine dergisi bulunurken, yeşil küme sadece Journal of the American Medical Informatics Association ve Journal of Medical Internet Research dergilerinden oluşan bir kümedir ve küme içi bağ da çok güçlü görünmemektedir.

\section{Sosyal Ağlar}

Sosyal Ağlar yazarlar, kurumlar ve ülkeler arası iş birliği ağlarıyla incelenmiştir. Ağlar oluşturulurken en etkili 50 yazar, en çok iş birliği yapan 50 kurum ve en az iki yayına sahip 50 ülke dikkate alınmış olup Louvain Algoritmasına göre renklerle kümelenmiştir. Görsellerdeki her bir elips bir yazar, kurum veya ülkeyi ifade etmekte olup aralarındaki çizgilerin kalınlığı iki yazar, kurum veya ülke arasındaki ilişkinin yoğunluğuna göre değişmektedir.

Yazarlar iş birliği ağı Şekil 7a'da yer almaktadır. A $\breve{g}$ yapısı incelendiğinde 15 farklı küme oluştuğu ve bu kümelerin yalnızca kendi aralarında iş birliği yaptığı kümeler arası iş birliği olmadığı görülmektedir. En çok iş birliği ağına sahip olan Kripalani, aynı zamanda en büyük kümenin de merkezinde yer almaktadır. İkinci en büyük küme olan turuncu kümede ise Wolf merkezde bulunmakta ve Davis ile güçlü bir iş birliği ağı olduğu görülmektedir. Jan, Dewalt, Davis, Bates, Roter, Osborne ve Lee'nin ise ayrı kümeler oluşturmasına rağmen bu kümelerde de tek başlarına olduğu görülmekte ve hiç iş birliği yapmadıkları anlaşılmaktadır.

Şekil $7 b$ 'de verilen kurumlar arası iş birliği ağ 1 incelendiğinde 25 farklı küme oluştuğu görülmektedir. En çok iş birliği ağına sahip olan en büyük kümenin merkezinde Northwestern University olduğu görülmektedir. Bu üniversitenin Louisiana State University ile yoğun bir iş birliği ağı vardır. Mavi kümenin iş birliği ilişkisi bulunan gri ve bej kümelerin de mavi küme gibi tamamının Amerika'da yer alan üniversiteler olduğu görülmektedir. Yeşil küme ve kahverengi küme arasında da işbirliği olduğu görülmektedir. 16 adet kurumun ise hiçbir iş birliği bağ 1 bulunmamaktadır. Kümeler oluşurken turuncu küme hariç bütün kümelerin aynı ülkede bulunan kurumlar arasında oluşmuş olması dikkat çekmektedir. İstisna olan turuncu küme ise

Sağlık Okuryazarlığg Araştırmalarının Bibliyometrik Analizi Akyüz. 
Avustralya ve İngiltere merkezli kurumlardan oluşmaktadır.

Şekil 7c'de sunulan ülkeler arası iş birliği ağında en az iki yayına sahip 50 ülke dikkate alınmış ancak ağ oluşturulurken herhangi bir kümeye ait olmayan ülkeler ağdan çıkarılmıştır. Ülkeler arası iş birliği ağında beş kümelenme olduğu görülmektedir. Merkezinde Avustralya olan kırmızı küme en çok iş birliğine sahip olan merkez kümedir. Amerika'nın merkezinde olduğu yeşil küme ise en kalabalık küme olarak dikkat çekmektedir. Avustralya ve Birleşik Krallık arasındaki çizginin kalınlığından da anlaşılacağı üzere bu iki ülke arası iş birliği çok kuvvetlidir. Avustralya daha sınırlı sayıda ülkeyle yoğun iş birlikleri kurarken Amerika daha çok sayıda ülkeyle daha zayıf iş birlikleri kurmuştur.

Bibliyometrik analiz sonucunda tek ülkeli yayın (SCP) ve çok ülkeli yayın (MCP) değerlerine göre ülkelerin sıraları değerlendirildiğinde, toplam yayın sayısında Amerika çok büyük bir farkla ilk sırada olmasına rağmen MCP oranı olarak belirtilen ve diğer ülkelerle iş birliği içerisinde yayımlanan makale sayısının toplam makale sayısına bölünmesiyle elde edilen sıralamada Avustralya ve İngiltere'nin çok gerisinde kaldığı görülmüştür. Türkiye bu alanda yalnızca iki makale ile en etkili ülkeler sıralamasında ilk 20'ye girememiş ve hiçbir ülkeyle iş birliği içerisinde bulunmamıştır.

\section{Tartışma}

Bu çalışma bulgularından sağlık okuryazarlı̆̆ makale sayılarında özellikle son yıllarda belirgin bir artış olduğu ve sağlık okuryazarlığı ile ilgili literatürün katlanarak büyüdüğü açıkça görülmektedir. Nitekim Bazm ve ark. tarafindan yapılan çalışmada da sağlık okuryazarlığı alanında yapılan çalışmaların sayısının hızlı bir şekilde arttığ belirtilmiştir (29). Benzer şekilde Kondilis ve ark. tarafından ABD ve Avrupa Birliği ülkelerinde 1991-2005 y1llarını kapsayacak şekilde gerçekleştirilen çalışmada da konuyla ilişkili çok sayıda yayın yapıldığı belirlenmiştir (10). Bankson tarafından yapılan ve 1997-2007 yıllarını kapsayan sağlık okuryazarlığına ilişkin bibliyometrik analiz çalışması sonuçları da benzer bulguları ortaya koymuştur. Çalışmanın kapsadığı yıllarda sürekli bir artış olduğu ve özellikle 2003 yılından itibaren bu artışın çok daha belirgin olarak görüldüğü belirtilmiştir. Bu artışta Amerikan Tıp Derneğinin 2003 yılında yayınladığı "Health Literacy: A Manual for Clinicians" adlı yayının etkili olduğu değerlendirilmiştir (21). Sağlık okuryazarlığı konusunda yapılmış başka çalışmalarda da yukarıdaki çalışma bulgularını destekleyen bulgular ortaya konmuştur $(22,30)$.

$\mathrm{Bu}$ çalışma sonuçlarına göre sağlık okuryazarlığı alanında yayınlanan makaleler incelendiğinde, gelişmiş ülkelerin özellikle de $\mathrm{ABD}$, Avustralya, Kanada, Almanya ve İngiltere'nin diğer ülkelere oranla belirgin bir üstünlüğünün olduğu görülmektedir. Benzer bulgular Kondilis ve ark. tarafindan yapılan çalışmada da görülmüş, ABD'de Avrupa Birliği ülkelerinin yapmış olduğu yayınların üç katından daha fazlasının yayınlandığı belirlenmiştir (10). Bulguları bu çalışma ile paralellik gösteren 2005-2014 yıllarını kapsayan başka bir çalışmada da ABD’nin sağlık okuryazarlı̆̆ konusundaki yayınlarda lider olduğu, bu ülkeyi Kanada ve İngiltere'nin takip ettiği görülmüştür (29). Bu durumun, gelişmiş ülkelerin genel akademik seviyelerinin yüksekliğinden kaynaklanabileceği ifade edilebilir. Benzer şekilde, konuya ilişkin en verimli yazarlar ve en fazla sayıda makale yayınlayan dergiler söz konusu olduğunda da aynı ülkeler öne çıkmaktadır. Ülkelerin genel akademik seviyelerinin incelendiğ birtakım analizlerde yer almayan Avustralya'nın, konu sağlık okuryazarlığı olduğunda en başarılı ülkelerden olması bu ülkede konuya verilen önemi göstermektedir. Türkiye tek merkezli ve ülkeler arası iş birliği ile yapılan yayınların sıralandığı değerlendirmede, ilk 20 ülke arasında yer almamaktadır. Bu alanda Türkiye menşeili yalnızca iki makalenin yayımlandığı tespit edilmiştir.

$\mathrm{Bu}$ çalışmada sağlık okuryazarlığı konusundaki yayınların en fazla Patient Education and Counseling dergisinde yer aldığ dergiyi ikinci olarak aynı sayıda yayınla Journal of General Internal Medicine ve BMC Health Services Research dergilerinin takip ettiği belirlenmiştir. $\mathrm{Bu}$ çalışma bulgularını destekleyen bir başka çalışmada da Patient Education and Counseling dergisinin ilk sırada Journal of General Internal Medicine dergisinin ise ikinci sırada yer aldığı görülmüştür. Aynı çalışmada bu çalışmada da olduğu gibi Journal of Health Communication dergisinin ise dördüncü sırada yer aldığı belirlenmiştir (22). Bankson tarafından yapılan çalışmada da Journal of General Internal Medicine dergisinin sağlı okuryazarlığı konusunda en fazla yayını içeren dergi olduğu belirlenmiştir. Aynı çalışmada Patient Education and Counseling dergisinin sağlık okuryazarlığı konusunda en fazla yayın içeren dördüncü dergi olduğu ortaya konmuştur (21). Bu çalışma bulgusuyla da paralellik gösteren bu bulgu Patient Education and Counseling dergisinin 2007 y1lindan itibaren sağlık okuryazarlığı konusunda daha fazla yayın kabul ettiği ve alanda öne çıkan bir dergi haline geldiğini göstermektedir. Bankson tarafından yapılan çalışmada Journal of Health Communication dergisi yayın sayısına göre beşinci sırada yer alırken bu çalışma bulgularına göre de dördüncü sırada yer almıştır. Bu bulgu Journal of Health Communication dergisinin alanda halen önemli bir dergi olarak yer aldığını göstermektedir.

Kentucky Üniversitesinde yapılan 1980-2010 yıllarını kapsayan bir çalışmada sağlık okuryazarlığ 1 konusunda yayın sayısına göre yazar sıralamasında Wolf MS, Davis TC, Parker RM ilk üç sırada yer alırken Paasche-Orlow MK altıncı ve Kripalani S ön dördüncü sırada yer almıştır (22). Bu çalışma bulgularına göre ise yayın sayısına göre en fazla yayın sahibi ilk beş yazarın sırasıyla Kripalani S, Wolf MS, Davis TC, Paasche-Orlow MK ve Parker RM olduğu belirlenmiştir. $\mathrm{Bu}$ bulgular ve bu araştırmada ortaya konan yazara ilişkin diğer bulgulardan da görüldüğü gibi Kripalani 2010 yılından sonra sağlık okuryazarlığı alanında lider yazar olmuş ve alana çok büyük katkılar vermiştir.

$\mathrm{Bu}$ çalışmanın yazarlar arası iş birliği ağı analiz bulgularında Kripalani en büyük kümenin merkezinde yer alırken bu yazar dışında Wolf, Davis, Jan, Dewalt, Davis, Bates, Roter, Osborne ve Lee öne çıan diğer yazarlar olarak belirlenmiştir. 1980-2010 y1llarını kapsayan başka bir çalışmada ise Wolf, Parker, Davis, Jorm, Schillinger ve Paasche-Orlow adlı yazarların öne çıktığı belirlenmiştir (22). Bu bulgular 2010 yılından itibaren Kripalani'nin sağlık okuryazarlığı alanında etkili bir yazar haline geldiğini ve diğer yazarlarla iş birliği içerisinde olduğunu, Wolf ve Davis'in de alanda etkisinin devam ettiğini göstermektedir.

$\mathrm{Bu}$ çalışmanın yazar ortak atıf ağı analiz bulgularında Parker, Gazmararian, Williams, Weiss, Berkman ve Nielsen-Bohlman ön plana çıkmıştır. Yapılan başka bir çalışmada ise Parker, Baker, Davis, Gazmararian, Weiss'in ön planda olduğu görülmüştür (22). Bu bulgular bu araştırma bulgularına paralellik göstermektedir. 
Bu çalışmada analiz edilen doküman atıf ağında Berkman (2011-1), Nielsen-Bohlman (2004-1), Parker (1995), Chew (2004-1) ve Chew (2008) yayınları daha belirgin olarak ön planda görülmüştür. Başka bir çalışmada ise çalışmanın yapıldı ğı dönem itibariyle Parker (1995), Parker (1999), Williams (1995) ve Davis (1993) yayınlarının alanda daha etkili olduğu belirlenmiştir (22).

Çalışma kapsamında yapılan yazar anahtar kelime bulutunda en fazla tekrar edilen ve görsel olarak da en belirgin şekilde izlenen kelimeler "health literacy", "primary care", "health", "literacy", "communication", "patient education" ve "education" kelimeleri olmuştur. Shapiro ve ark. tarafından yapılan çalışmada benzer kelimelerin öne çıktığ 1 belirlenmiştir. Çalışmada "health literacy", "knowledge", "communication", "care", "literacy" ve "education" kelimelerinin en fazla tekrarlanan kelimeler olduğu belirlenmiştir (22). Baji ve ark. tarafından yapılan çalışmada görselleştirilen kelime bulutunda ise "health literacy", "health", "mental health literacy", "literacy", "communication" ve "education" kelimelerinin daha belirgin olarak ortaya çıktığı görülmüştür (30).

\section{Sonuç ve Öneriler}

Sağlık okuryazarlığı konusunda literatürde yapılan inceleme sonunda bu çalışmanın R tabanlı bibliometrix programı kullanılarak yazılan ilk ulusal makalelerden biri olma özelliği taşıdığı tespit edilmiştir.

Türkiye'de ilgili kamu kurumları tarafından yürütülen konuya ilişkin araştırma sonuçlarına göre yaklaşık olarak 10 kişiden yedisinin sağl1k okuryazarlığı düzeyinin olması gerekenden düşük veya sınırlı seviyede olduğu tespit edilmiştir. Ancak özellikle son yıllarda Sağlık Bakanlığı tarafından hayata geçirilen çalışmalar, düzenlenen etkinlikler ve hazırlanan dokümanlarla sağlık okuryazarlığı düzeyinin artırılmasına çalışılmaktadır.

Sağl1k okuryazarlı̆̆ konusunda gelişmiş ülkeler tarafından üretilen araştırmalar, gelişmekte olan ülkelere kıyasla daha etkilidir ve dünyadaki diğer araştırmacılar üzerinde daha fazla etkiye sahiptir. Bunun nedeninin, gelişmiş ülkelerde sağlanan teşvik edici fonların, yeterli tesislerin, kapsamlı teknik desteğin ve nitelikli eğitim/ öğretimin olabileceği ifade edilebilir.

Yapılan bir araştırma, düşük gelirli bir nüfusun yüksek gelirli bir nüfustan daha düşük bir ortalama sağlik okuryazarlığı seviyesine sahip olduğunu göstermiştir (31). Sağlık okuryazarllğı düzeyleri, ülkeler arasında ve ülke içi sosyo-demografik gruplar arasında büyük farklılıklar göstermektedir. Sağlık okuryazarlığının düşük olduğu nüfus, nüfusun kalanına göre bu durumdan orantısız bir şekilde olumsuz etkilenmektedir. $\mathrm{Bu}$ da ciddi sağlık eşitsizliklerine sebep olmaktadır. Sağlık okuryazarlığını geliştirmek ve bu dengesizliği gidermek için sağlık okuryazarlığının kritik halk sağlığı eylemi olarak kabul edilmesi gerekmektedir.

Sağlık okuryazarlığı, insanların kendi sağlıkları ve ailelerinin sağlığı hakkında bilinçli kararlar vermeleri, sağlıklarına ilişkin kararlara aktif olarak katılmaları, sağlık hizmetleri sistemlerinde etkili bir şekilde söz sahibi olarak haklarını karar vericiler nezdinde etkin şekilde savunmaları açısından hayati öneme sahiptir. Sağlık okuryazarlığının bir başka alt başlığı olan örgütsel sağlık okuryazarlığ ise, kuruluşların ve sistemlerin sağlık bilgilerini ve kaynaklarını insanlar için kullanılabilir ve erişilebilir hale getirme biçimidir. Daha güçlü sağlık okuryazarlığı ve sağlık okuryazarlığı duyarlılığı, sağlık hizmetlerini bireysel yeteneklere bakılmaksızın herkes için erişilebilir hale getirerek sağlık sonuçlarında eşitliği sağlayacak bir faktördür.

Sağlık sistemindeki karar vericilerin, sağlık okuryazarlığının geliştirilmesi için gerekli yatırımların yapılmasını sağlamaları ve sağlık okuryazarlığını sürdürülebilir kalkınma hedeflerine ulaşmak için temel basamaklardan biri olarak kabul etmeleri gerekmektedir. Kamusal ve toplumsal düzeylerdeki aktörlerin bu hedeflerin gerçekleşmesi amacıyla iş birliği içerisinde olması büyük önem taşımaktadır.

Düşük sağlık okuryazarlığı, daha sağlıksız seçimler, daha riskli sağlık davranışı, daha kötü sağlık durumu, daha niteliksiz öz bakım, daha yüksek maliyetler ve sağlık hizmetlerinin uygunsuz kullanımı ile ilişkilendirilebilir. Sağlık sistemlerinin daha etkili ve verimli olmasında sağlık okuryazarlığı seviyesinin artırılması önemli bir araçtır.

\section{Kaynaklar}

1.Kickbusch I, Pelikan J, Apfel F, Tsouros A. Health literacy. Copenhagen: WHO Regional Office for Europe; 2013.

2.Baker DW, Williams MV, Parker RM, Gazmararian JA, Nurss J. Development of a brief test to measure functional health literacy. Patient Education and Counseling 1999;38(1):33-42.

3.Kripalani S, Weiss BD. Teaching about health literacy and clear communication. Journal of General Internal Medicine 2006;21(8):888-90.

4.Baker DW, Parker RM, Williams MV, Clark WS, Nurss J. The relationship of patient reading ability to self-reported health and use of health services. American Journal of Public Health 1997;87(6):1027-30.

5.Nutbeam D, Kickbusch I. Advancing health literacy, a global challenge for the 21th century. Health Promot Int 2000;15:259-67.

6.Zibellini J, Muscat DM, Kizirian N, Gordon A. Effect of health literacy interventions on pregnancy outcomes: A systematic review. Women and Birth 2021;34(2):180-6.

7.Nash S, Arora A. Interventions to improve health literacy among Aboriginal and Torres Strait Islander Peoples: A systematic review. BMC Public Health 2021;21(1):1-15.

8.Shnaigat M, Downie S, Hosseinzadeh H. Effectiveness of health literacy interventions on COPD self-management outcomes in outpatient settings: A systematic review. COPD: Journal of Chronic Obstructive Pulmonary Disease 2021:1-7.

9.Vernon JA, Trujillo A, Rosenbaum SJ, DeBuono B. Low health literacy: Implications for national health policy 2007. Available from: https://hsrc.himmelfarb.gwu.edu/cgi/ viewcontent.cgi?article $=1173 \&$ context $=$ sphhs_policy_facpubs.

10.Kondilis BK, Kiriaze IJ, Athanasoulia AP, Falagas ME. Mapping health literacy research in the European Union: A bibliometric analysis. PLoS One 2008:3(6):e2519.

11.Norman CD, Skinner HA. eHealth literacy: essential skills for consumer health in a networked world. Journal of Medical Internet Research 2006;8(2):e9.

12.Sørensen K, Pelikan JM, Röthlin F, et al. Health literacy in Europe: comparative results of the European health literacy survey (HLS-EU). European Journal of Public Health 2015;25(6):1053-8.

13.Bozkurt H, Demirci H. Health literacy among older persons in Turkey. The Aging Male 2019;22(4):272-7.

14.Özdemir H, Alper Z, Uncu Y, Bilgel N. Health literacy among adults: A study from Turkey. Health Education Research 2010;25(3):464-77.

15.Arias KM. Outbreak investigation, prevention, and control in health care settings: Critical issues in patient safety: Jones \& Bartlett Publishers; 2010

16.Chen C. Science mapping: A systematic review of the literature. Journal of Data and Information Science 2017;2(2):1-40.

Sağlık Okuryazarlığı Araştırmalarının Bibliyometrik Analizi Akyüz. 
17.Kurutkan M, Orhan F. Kalite prensiplerinin görsel haritalama tekniğine göre bibliyometrik analizi: Sage Yayıncılık San. Tic. ve Ltd. Şti; 2018.

18.Kurutkan M, Orhan F. Sağlık politikası konusunun bilim haritalama teknikleri İle analizi: IKSAD Publications; 2018.

19.Zupic I, Čater T. Bibliometric methods in management and organization. Organizational Research Methods 2015;18(3):429-72.

20.Aria M, Cuccurullo C. Bibliometrix: An R-tool for comprehensive science mapping analysis. Journal of Informetrics 2017;11(4):959-75.

21.Bankson HL. Health literacy: An exploratory bibliometric analysis, 1997-2007. Journal of the Medical Library Association: JMLA 2009;97(2):148.

22. Shapiro RM. Health literacy: A bibliometric and citation analysis. Master's Theses: University of Kentucky; 2010

23.Nasir A, Shaukat K, Hameed IA, et al. A bibliometric analysis of corona pandemic in social sciences: a review of influential aspects and conceptual structure. IEEE Access 2020 .

24.Güley AÖ, Kurutkan MN. Sağlık hizmetlerinde kalite kavramının bibliyometrik analizi: Çalıșmalar ve eğilimler. Journal of Innovative Healthcare Practices 2021;2(1):122 .

25.Bornmann L, Daniel HD. What do we know about the $h$ index? Journal of the American Society for Information Science and Technology 2007;58(9):1381-5.

26.Harzing A-W. Reflections on the h-index. Business\&Leadership 2012;1(9):101-6.

27.Thamaraiselvi M, Lakshmi S, Manthiramoorthi M. Correlation of authorship pattern, Lotka's law and collaborative measures on research publications of Anna University: A bibliometric study. Library Philosophy and Practice 2021:1-12.

28. Wang C, Lim MK, Zhao L, et al. The evolution of Omega-The International Journa of Management Science over the past 40 years: A bibliometric overview. Omega 2020;93:102098.

29.Bazm S, Bazm R, Sardari F. Growth of health literacy research activity in three Middle Eastern countries. BMJ Health \& Care Informatics 2019;26(1)

30.Baji F, Azadeh F, Parsaei Mohammadi P, Parmah S. Mapping intellectual structure of health literacy area based on co-word analysis in web of science database during the years 1993-2017. Health Information Management 2018;15(3 (61)):139-45.

31.Sanders LM, Federico S, Klass P, Abrams MA, Dreyer B. Literacy and child health: A systematic review. Archives of Pediatrics \& Adolescent Medicine 2009;163(2):131-40. 
Şekil 1. Çalışmanın İş Akış Şeması

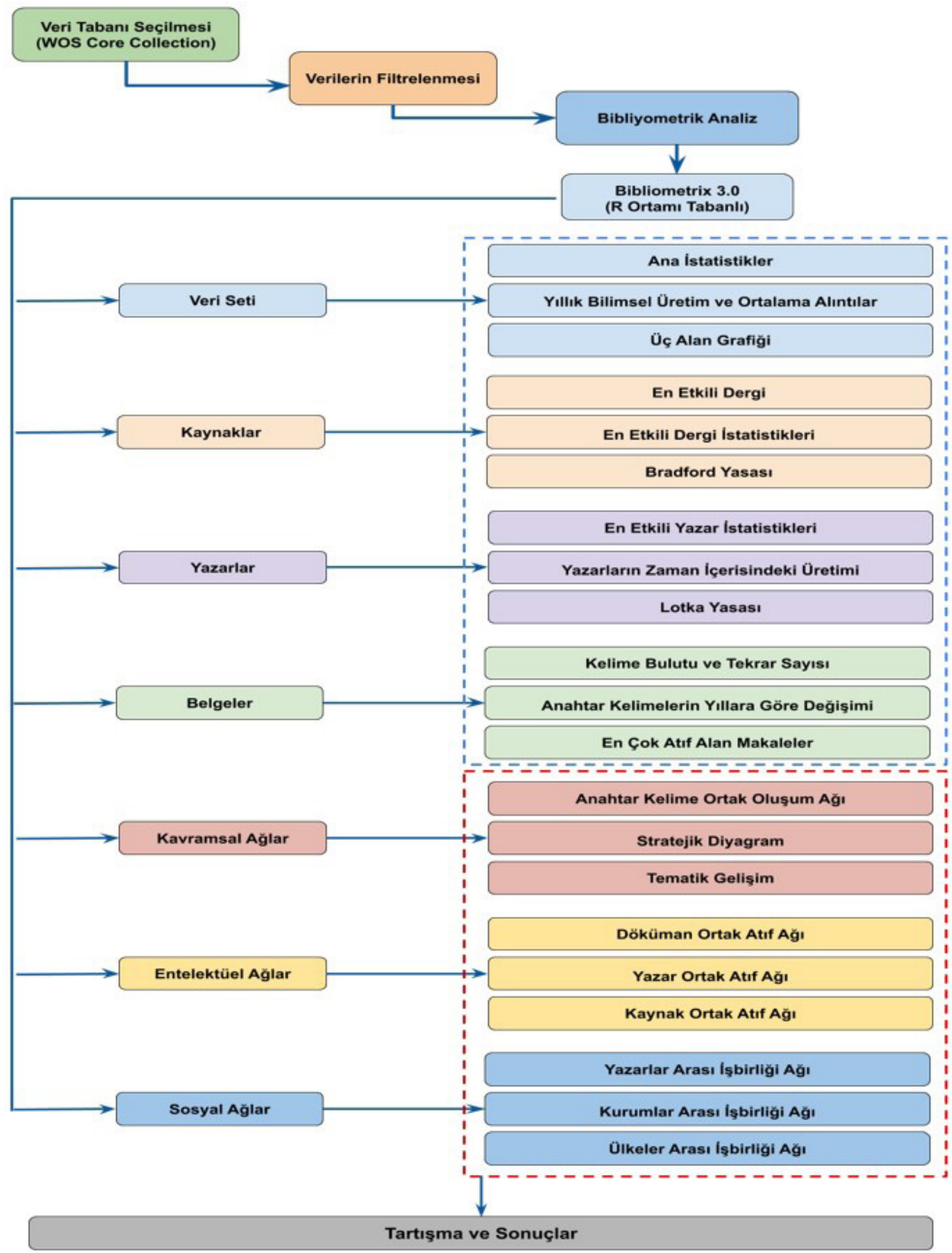




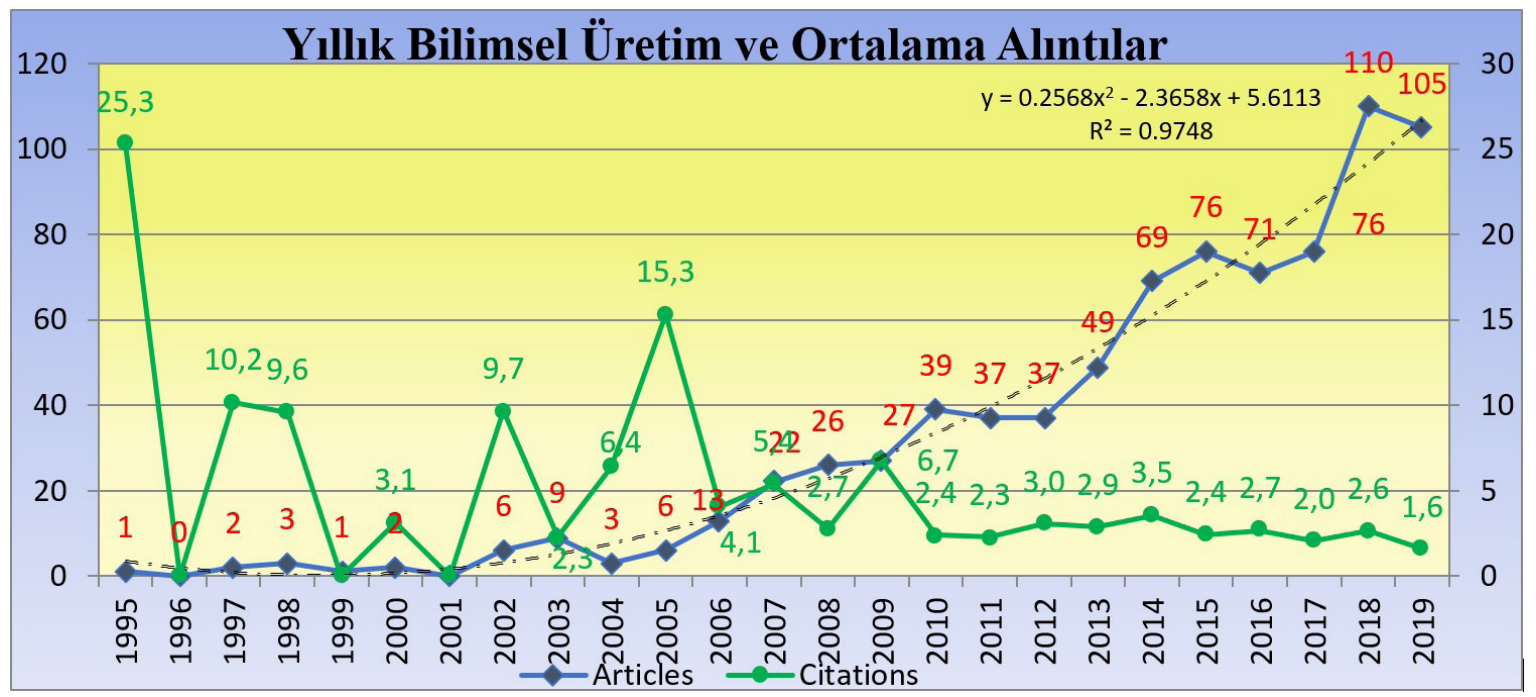

Şekil 3. Yazarların Zaman İçindeki Üretimi ve Lotka Yasası Grafiği
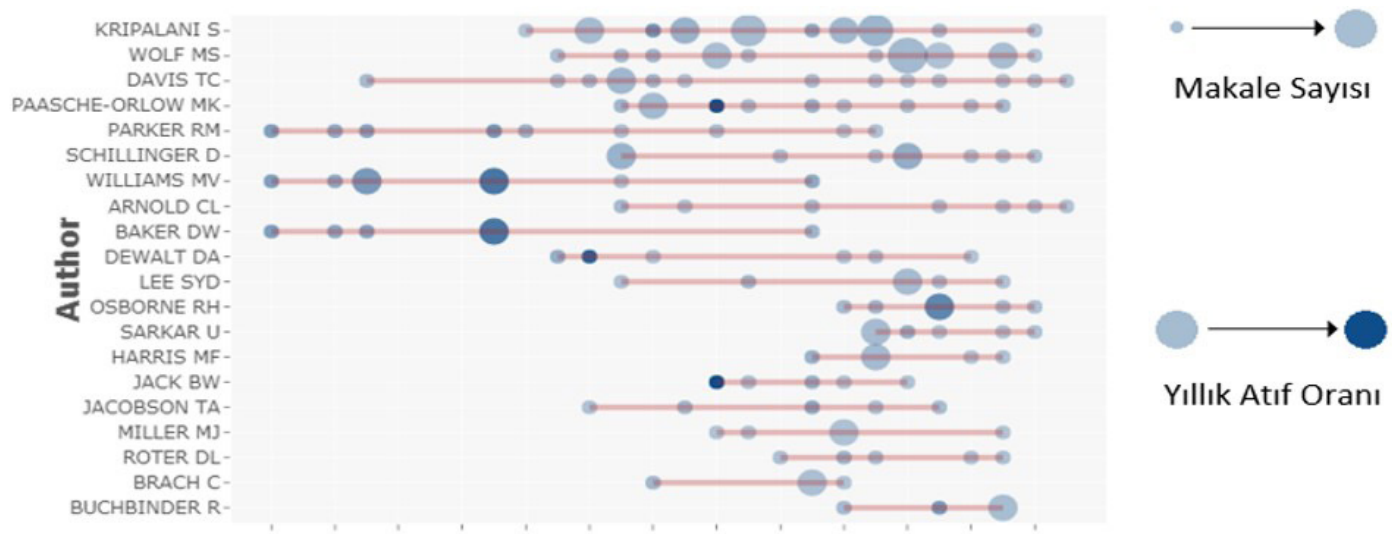

Yıllık Atıf Oranı

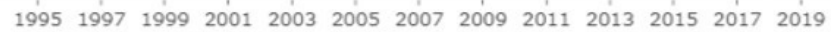

Year

a. En Etkili Yazarların Zaman İçindeki Üretimi

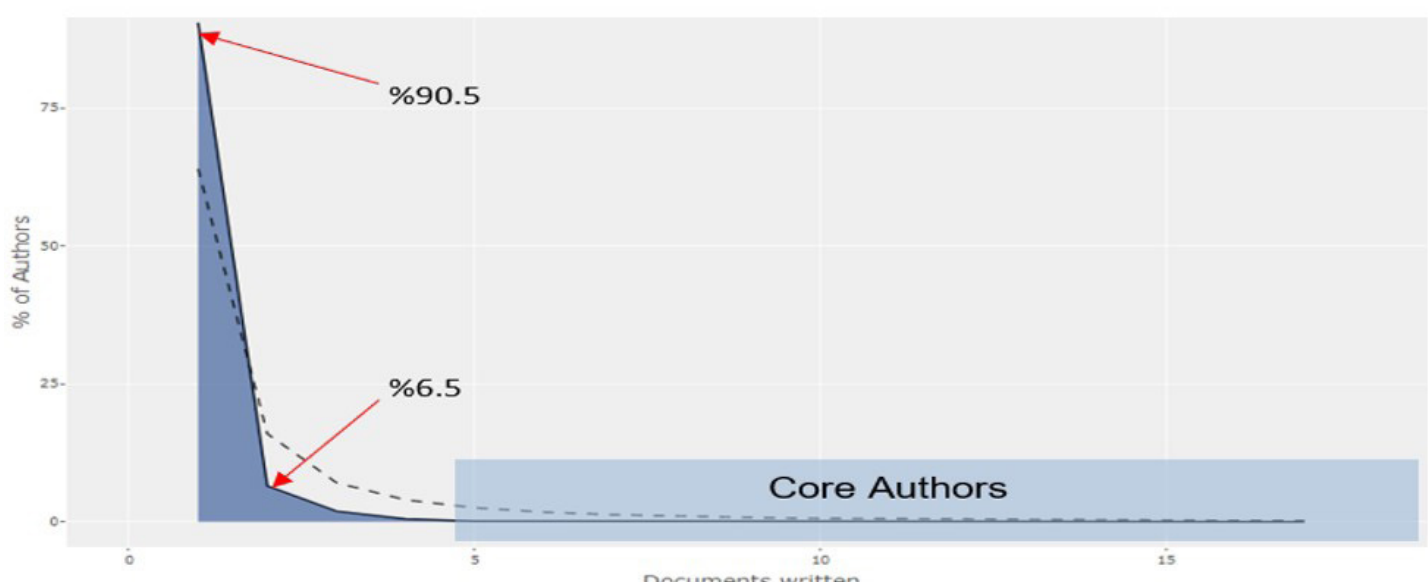

b. Lotka Yasası Grafiği 
Titles
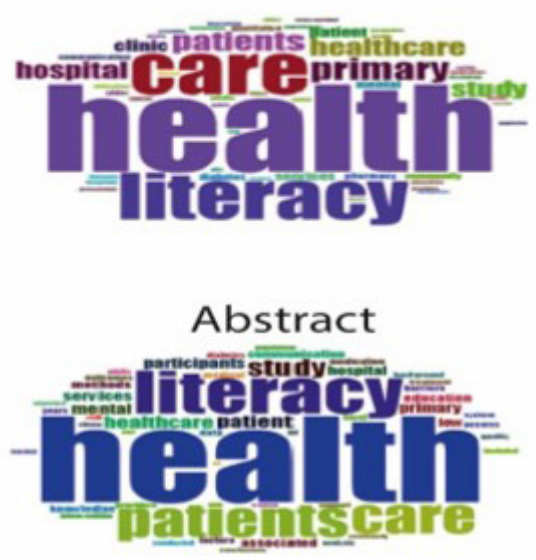

Author's Keywords

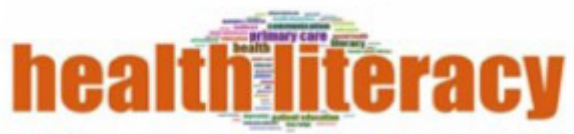

Keywords Plus

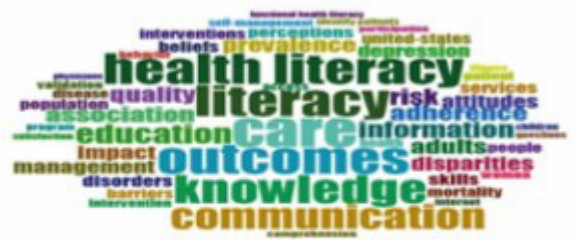

Tekrar Sayısı
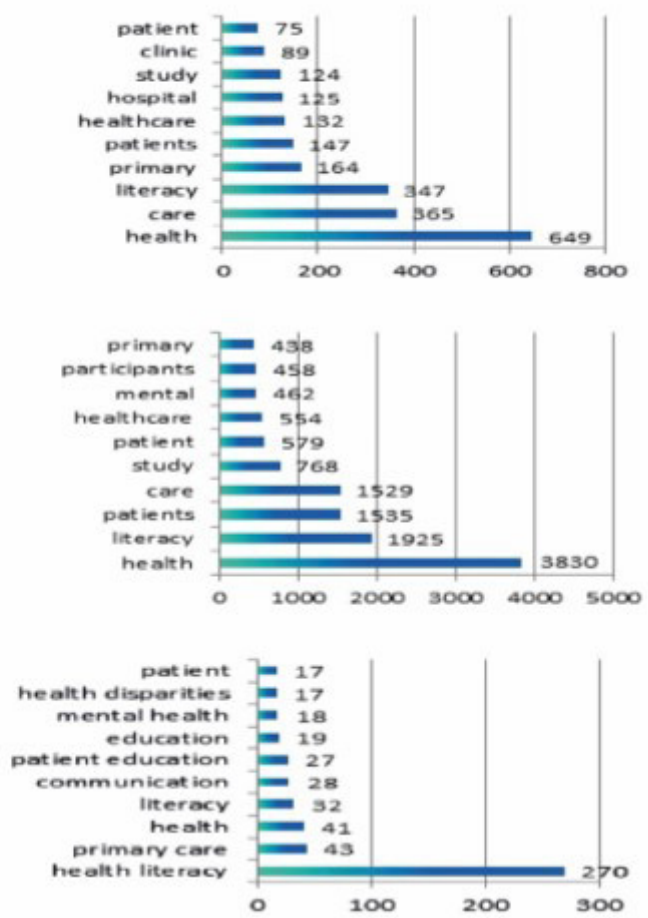

a. Kelime Bulutları

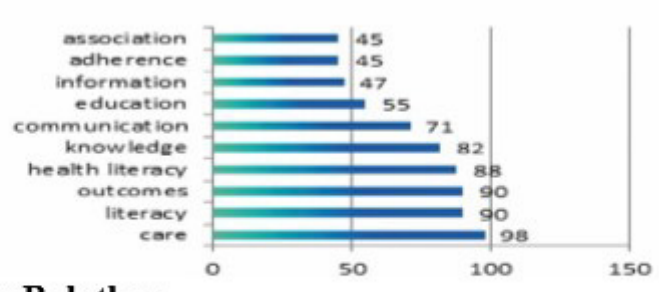

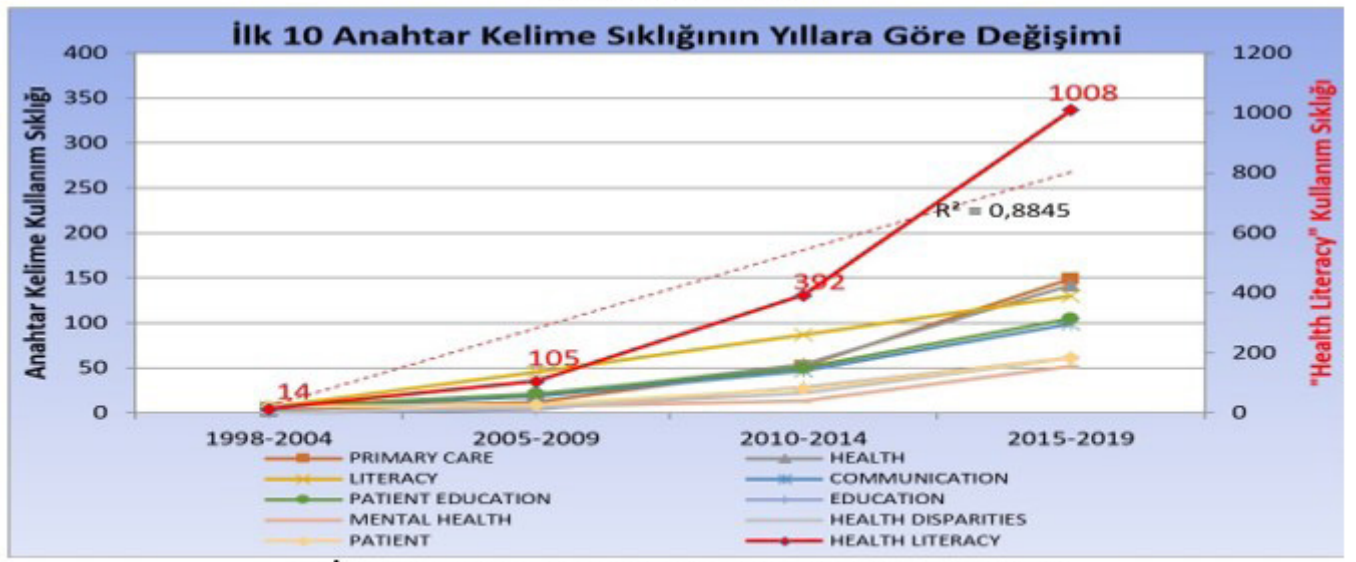

b. İlk 10 Anahtar Kelimenin Yıllara Göre Değișimi 

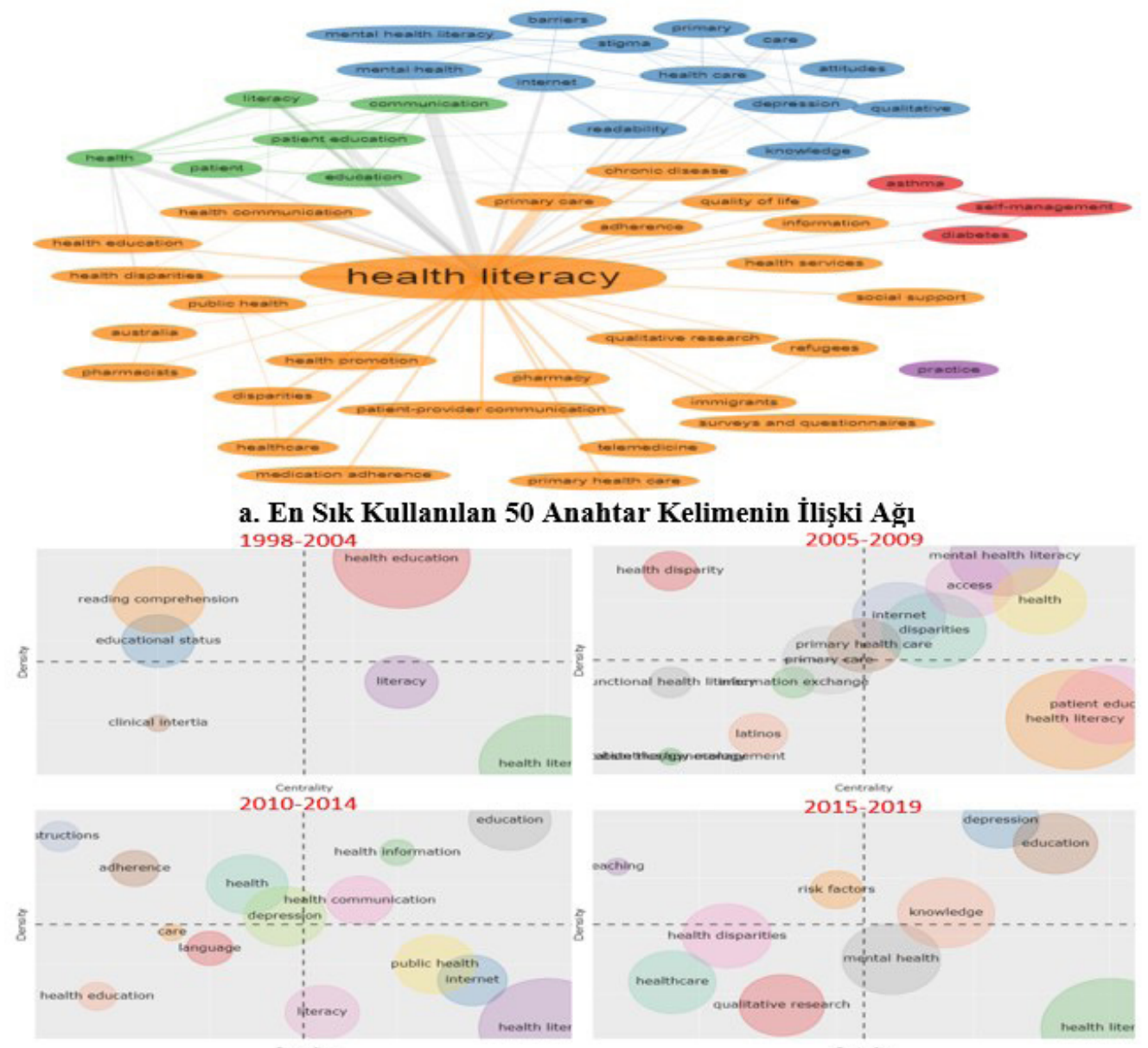

b. Anahtar Kelimelerin Stratejik Diyagramı

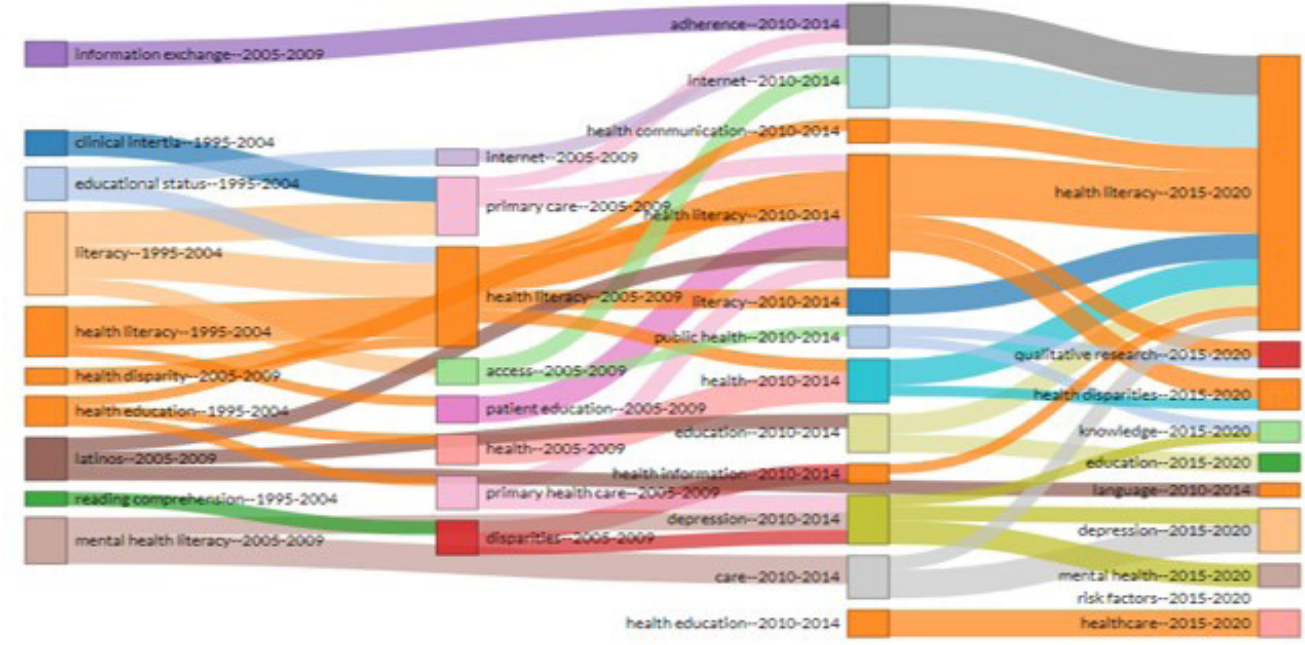

\section{c. Tematik Evrim Haritası}




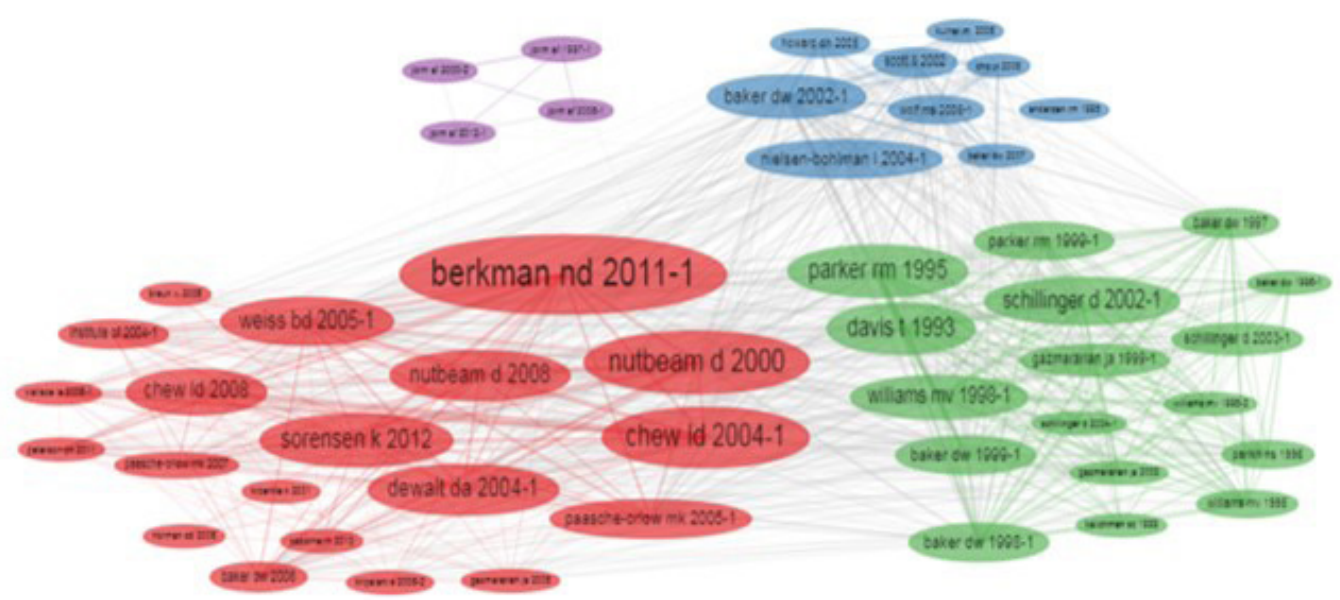

a. Doküman Ortak Atıf Ağı
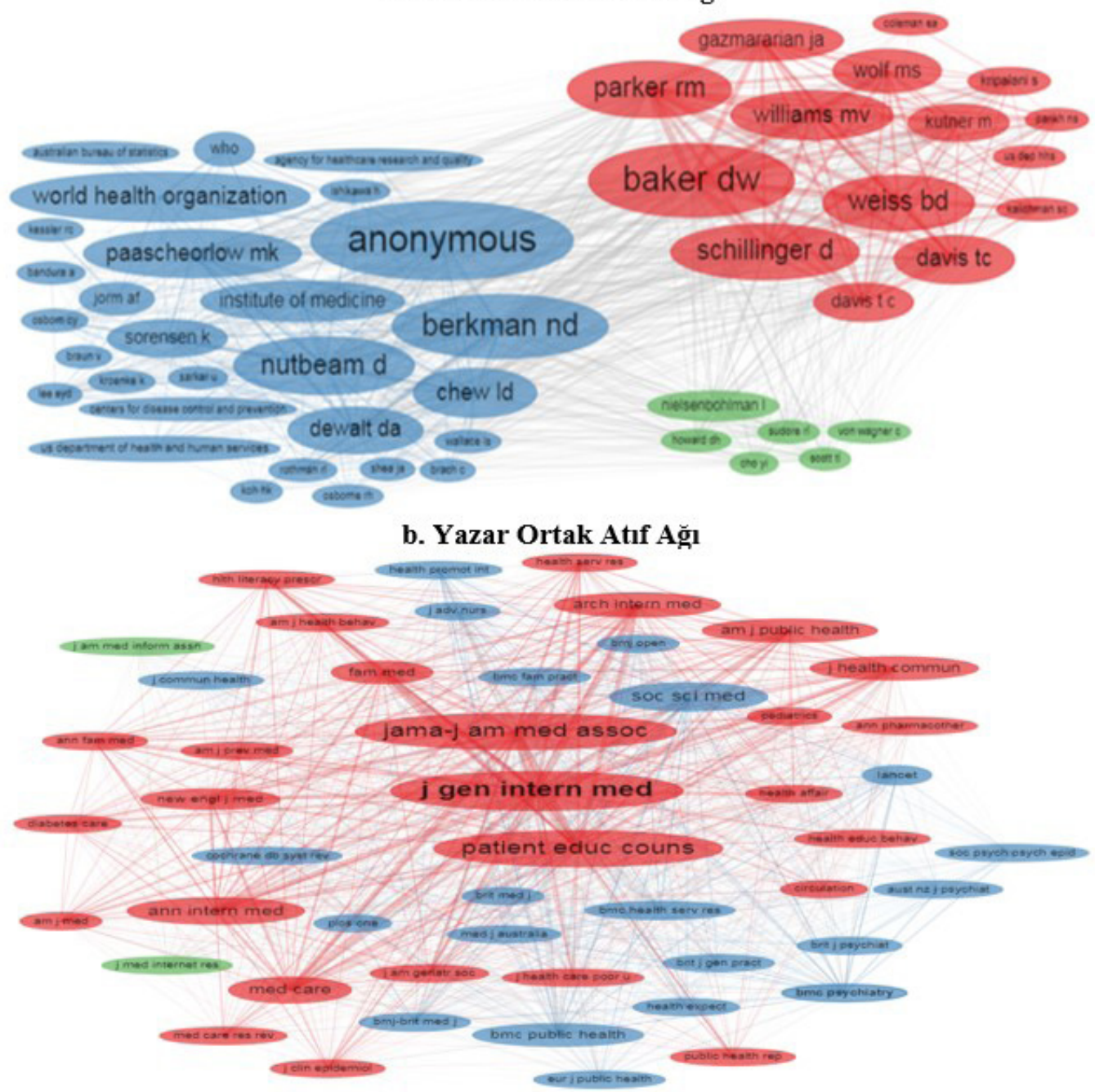

c. Kaynak Ortak Atıf Ăğ 
Şekil 7. Sosyal Ağlar
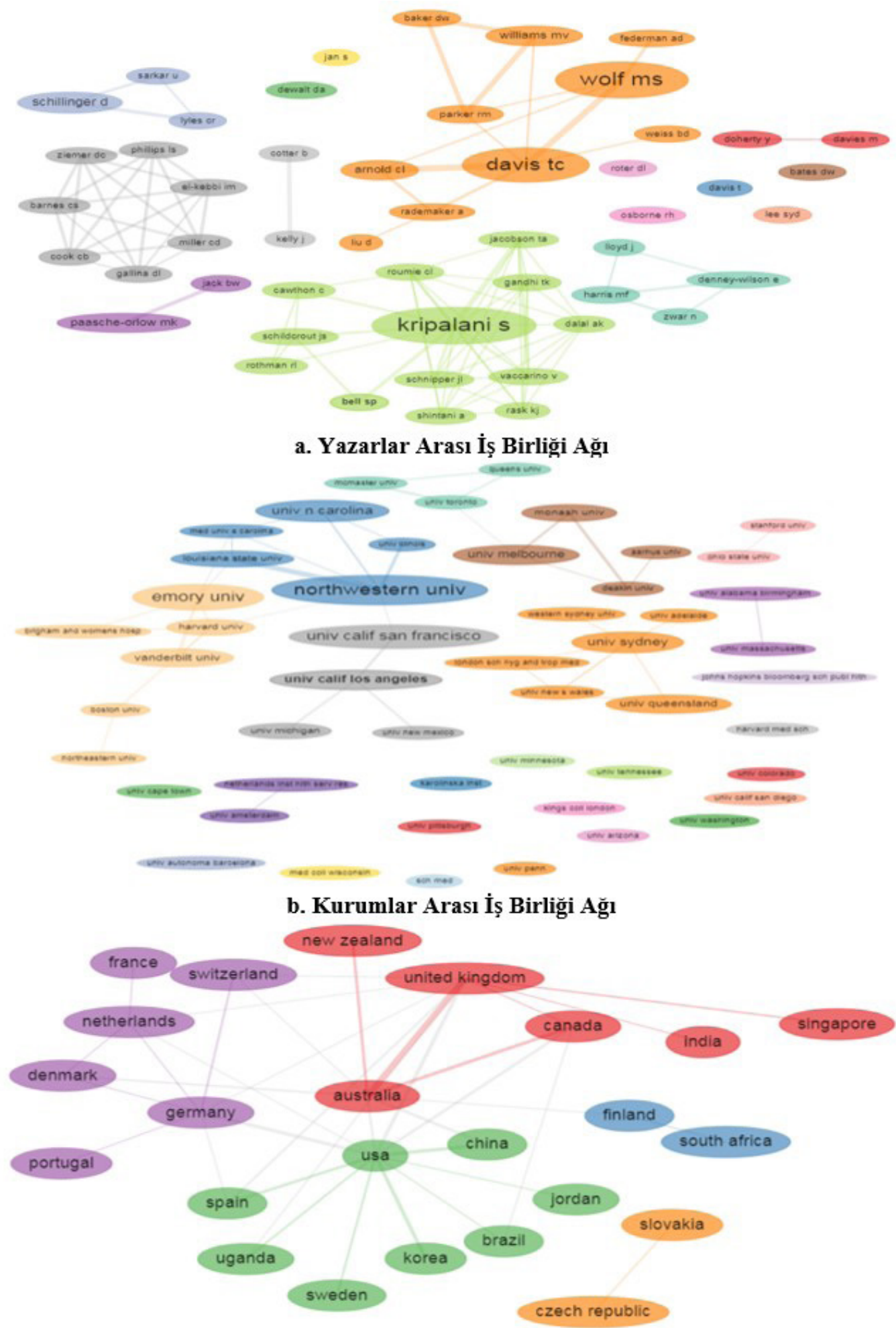

c. Ülkeler Arası İș Birliği Ağı 